Journal of maternal and child health (2018), 3(2): 138-145

https://doi.org/10.26911/thejmch.2018.03.02.06

\title{
Biopsychosocial Factors Associated with Preterm Birth at Dr. Moewardi Hospital, Surakarta, Central Java
}

\author{
Harrys Bachtiar'), Uki Retno Budihastuti2), Harsono Salimo3) \\ 1)Masters Program in Public Health, Universitas Sebelas Maret \\ 2)Department of Obstetrics and Gynecology, Dr. Moewardi Hospital, Surakarta \\ 3)Department of Pediatrics, Dr. Moewardi Hospital, Surakarta
}

\begin{abstract}
Background: Preterm birth has been defined asgestational age of birth between 28 and 37 weeks. Prematurity is a major public health issue as studies have shown it increases the risk of mortality and morbidity of the newborns. The purpose of this study was to examine biopsychosocial factors associated with preterm birth.

Subjects and Method: This was an analytic observational with a case control design. The study was carried out at Dr. Moewardi Hospital, Surakarta, Central Java, from April to May 2018. A total sample of 200 of the newborn infants was selected for this study by fixed disease sampling, composing of 100 preterm newborns and 100 term newborns. The dependent variable was prematurity. The independent variables were maternal age, nutritional status, parity, ambient smoke exposure, maternal education, family income, and family support. The data on prematurity was obtained from medical record. The other variables were measured by a set of questionnaire. The data were analyzed by path analysis.

Results: Preterm birth was positively associated with maternal age $<20$ or $\geq 35$ years $(b=1.58$; CI $95 \%=0.65$ to $2.50 ; \mathrm{p}<0.001)$, ambient smoke exposure $(\mathrm{b}=1.42 ; \mathrm{CI} 95 \%=0.41$ to $2.44 ; \mathrm{p}=0.006)$, and parity $(\mathrm{b}=1.77 ; \mathrm{CI} 95 \%=0.87$ to $2.67 ; \mathrm{p}<0.001)$. Preterm birth was negatively associated with good maternal nutritional status $(b=-2.00$; CI 95\%= -2.92 to -1.08 ; $p<0.001)$. Good maternal nutritional status was positively associated with strong family support $(\mathrm{b}=0.93$; $\mathrm{CI} 95 \%=0.24$ to 1.61; $\mathrm{p}=0.008)$, high family income $(\mathrm{b}=2.26$; CI $95 \%=1.57$ to $2.95 ; \mathrm{p}<0.001)$, and high maternal education $(b=2.45$; CI $95 \%=1.76$ to 3.17 ; $<<0.001)$.
\end{abstract}

Conclusion: Preterm birth is positively associated with maternal age $<20$ or $\geq 35$ years, ambient smoke exposure, and parity, but negatively associated with good maternal nutritional status.

Keywords: preterm birth, biopsychosocial factors, path analysis

\section{Correspondence:}

Harrys Bachtiar. Masters Program in Public Health, Universitas Sebelas Maret, Surakarta, Jl. Ir. Sutami No.36 A, 57126, Surakarta, Central Java. Email: harrysbachtiar@gmail.com.

Mobile: +6285257311700 .

\section{BACKGROUND}

Premature births are births occurring in Week 28 to Week 37 (WHO, 2017). One of the causes of high morbidity and mortality in infants is that the babies are born prematurely. In addition, maternal health conditions during pregnancy greatly affect the pregnancy which is not good and healthy, and also can affect the fetus such as physical, psychological, environmental, social and cultural factors (Sulistyawati, 2009).
A study conducted by WHO 2012 (global action report on premature birth) showed that for about 15 million babies underwent premature birth and will continue to increase. Three-quarters of them can be saved at a cost effective today. From 184 countries, the rate of premature birth is about $5 \%$ to $18 \%$ of infants (Gebreslasie, 2016). From the WHO (2017) data, the incidence of preterm births in Indonesia from January to November 2017 was approxima- 
tely 675,700 live births and puts Indonesia

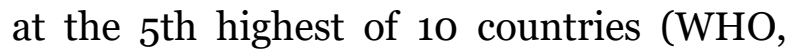
2017). Neonatal Mortality Rate (NMR) in Central Java Province in 2015 was 7.2 per 1,00o live births. The lowest districts/ municipalities with the lowest MMR are Surakarta 2.1 per 1,00o live births (Central Java Provincial Health Office, 2015).

Many risk factors affect premature birth including demographics (race, socioeconomic status, and age), general health factors (stress and illness that accompany pregnancy). There is a wide range of high risk of premature birth, including death, disease, disability, developmental development (Zhang et al., 2012).

\section{SUBJECTS AND METHODS}

This study was an analytic observational study with a case-controll design. The study was conducted at Dr. Moewardi hospital, Surakarta, from April to May 2018.

\section{Population and Sample}

The target population was all pregnant women in Dr. Moewardi hospital, Surakarta. The source population was taken from the Hospital which has a number of preterm births in Surakarta City. The sampling technique was fixed disease sampling technique with the sample size of 200 subjects, and using a ratio of 1:3. The number of case samples of 50 babies was born normal without congenital abnormalities and control samples for about 150 preterm infants without congenital abnormalities, then the drawing was done for sampling in each of the inpatient wards.

\section{Study Variables}

The independent variables in this study were maternal education, family income for pregnancy, pregnant nutritional status, family support, parity, maternal age, exposure to cigarette smoke, and nutritional sta- tus of pregnant women. The dependent variable was premature birth.

\section{Operational definition of variables}

Prematurity was defined as infants who were born at gestational age $<28$ weeks. The data were taken from medical record. The measurement scale was categorical.

Maternal age was defined as a measure of the length of life from birth to pregnancy, calculated in units of years. The data were collected by questionnaire. The measurement scale was categorical, coded 1 for $<20$ years old or $>35$ years old and o for 20 - 35 years old.

Maternal education was defined as a history of educational status of the highest school graduation achievement that has been pursued by the subject of study. The measurement scale was categorical, coded 1 for $<$ Senior High School or $\geq$ Senior High School.

Income for the family of pregnancy was defined as the total amount of income earned from the family members, either in the fixed or sideline income within one month and expressed in rupiah value. The data were collected by questionnaire. The measurement scale was continuous, but for the purpose of data analysis, it was transformed into dichotomous.

The maternal age was defined as a measure of the length of life from birth to pregnancy, calculated in units of years.

Maternal nutritional status was defined as measure of upper arm circumference (MUAC). The measurement scale was continuous, bur for the purpose of data analysis, it was transformed into dichotomous, coded o for good nutritional status if MUAC $\geq 23.5 \mathrm{~cm}$ and 1 for poor nutritional status if MUAC $<23.5 \mathrm{~cm}$.

Cigarette smoke exposure was defined as smoke from tobacco that has approximately 7,000 chemicals. Some of it is a substance that is not good for the body, 
including carbon monoxide (CO), polycylic aromatic hydrocarbons (PAHs), and so forth, and the contents of cancer triggers such as tar, benzopyrenes, vinyl chloride, and nicotine nitrosonor.

Parity was defined as a woman who has given birth to a live baby (viable) and is measured by parity more than four times, so they are more at risk of premature birth.

\section{Data Analysis}

Analysis of multivariate data by using path analysis was conducted to determine the magnitude of the influence of variables, either the direct or indirect influence. Pathway analysis steps were model specification, model identification, model conformity, parameter estimation and model respesification.

\section{Research Ethics}

The research ethics include research approval, anonymity, confidentiality and ethical approval. The ethical feasibility test was conducted in Dr. Moewardi hospital and declared as worthy of ethics based on decision letter number: 75/II/HREC/ 2018.

Table 1.The Characteristics of Subjects

\begin{tabular}{|c|c|c|c|}
\hline No. & Characteristics & Total (n) & Percentage (\%) \\
\hline \multirow[t]{3}{*}{$\mathbf{1}$} & Maternal Education & & \\
\hline & $<$ Senior High School & 66 & 33 \\
\hline & $\geq$ Senior High School & 134 & 67 \\
\hline \multirow[t]{3}{*}{2} & Family Income for Pregnancy & & \\
\hline & $<$ Minimum wage & 81 & 40.5 \\
\hline & $\geq$ Minimum wage & 119 & 59.5 \\
\hline \multirow[t]{3}{*}{3} & Family Support & & \\
\hline & Weak & 90 & 45 \\
\hline & Strong & 110 & 55 \\
\hline \multirow[t]{3}{*}{4} & Nutritional Status of Pregnancy (LiLA) & & \\
\hline & $<23.5 \mathrm{~cm}$ & 71 & 35.5 \\
\hline & $\geq 23.5 \mathrm{~cm}$ & 129 & 64.5 \\
\hline \multirow[t]{3}{*}{5} & Parity & & \\
\hline & Birth delivery $<4$ kali & 122 & 61 \\
\hline & Birth delivery $\geq 4$ kali & 78 & 39 \\
\hline \multirow[t]{3}{*}{6} & Smoke exposure & & \\
\hline & Low & 99 & 49.5 \\
\hline & High & 101 & 50.5 \\
\hline \multirow[t]{3}{*}{7} & Mother's age & & \\
\hline & $<20$ years old or $>35$ years old & 95 & 47.5 \\
\hline & $20-35$ years old & 105 & 52.5 \\
\hline
\end{tabular}

\section{Subject Characteristics}

Table 1 showed the age when most subjects of higher education ( $\geq$ Senior High School) ie $134(67 \%)$. It is also true for the family income for pregnancy, most of the subjects have high family income with the amount of 119 (5.5\%). Subjects mostly received strong family support of $110(55 \%)$.

As many as $64.5 \%$ mothers had had parity $<4$. The exposure to secondhand smoke on subjects is high with 101 (50.5\%), and the age of mothers with age 20-35 years is 105 (52.5).

\section{Bivariate Analysis of Premature Births}

Bivariate analysis was conducted to see the relationship of independent variables (maternal education, parity, maternal age, family income for gestation, exposure to cigarette smoke, family support and nutritional status of pregnant) and the dependent variable (premature birth). The result of bivariate analysis can be seen in table 2 . MUAC $\geq 23.5 \mathrm{~cm}$. As many as $61 \%$ mothers 
Table 2. Bivariate analysis of the study subjects

\begin{tabular}{|c|c|c|c|c|c|c|c|}
\hline \multirow{3}{*}{ Variable } & \multicolumn{4}{|c|}{ Birth } & \multirow{3}{*}{ OR } & \multirow{3}{*}{$\begin{array}{c}95 \% \\
\text { CI }\end{array}$} & \multirow{3}{*}{$\mathbf{p}$} \\
\hline & \multicolumn{2}{|c|}{ Normal } & \multicolumn{2}{|c|}{ Premature } & & & \\
\hline & $\mathbf{N}$ & $\%$ & $\mathbf{N}$ & $\%$ & & & \\
\hline \multicolumn{8}{|l|}{ Maternal education } \\
\hline$<$ Senior High School & 41 & 62.1 & 25 & 37.9 & \multirow{2}{*}{0.38} & & \multirow{2}{*}{0.003} \\
\hline$\geq$ Senior High School & 109 & 81.3 & 25 & 18.7 & & 0.73 & \\
\hline \multicolumn{8}{|c|}{ Family Income for the pregnancy } \\
\hline$<$ Minimum wage & 45 & 55.6 & 36 & 81 & \multirow{3}{*}{0.17} & $0.08-$ & \multirow{2}{*}{$<0.001$} \\
\hline$\geq$ Minimum wage & 105 & 88.2 & 14 & 11.8 & & 0.34 & \\
\hline \multicolumn{7}{|l|}{ Family support } & \\
\hline Weak & 51 & 56.7 & 39 & $43 \cdot 3$ & \multirow{2}{*}{0.15} & $0.07-$ & \multirow{2}{*}{$<0.001$} \\
\hline Strong & 99 & 90 & 11 & 10 & & 0.30 & \\
\hline \multicolumn{8}{|c|}{ Nutritional Status of Pregnancy (LiLA) } \\
\hline$<23,5 \mathrm{~cm}$ & 32 & 45.1 & 39 & 54.9 & \multirow{3}{*}{0.08} & $0.04-$ & \multirow{3}{*}{$<0.001$} \\
\hline$\geq 23,5 \mathrm{~cm}$ & 118 & 91.5 & 11 & 8.5 & & 0.17 & \\
\hline \multicolumn{6}{|l|}{ Parity } & & \\
\hline Birth delivery< 4 kali & 109 & 89.3 & 13 & 10.7 & \multirow{3}{*}{$7 \cdot 57$} & 3.66- & \multirow{2}{*}{$<0.001$} \\
\hline Birth delivery $\geq 4$ kali & 41 & 52.6 & 37 & 47.4 & & 15.65 & \\
\hline \multicolumn{7}{|l|}{ Smoke exposure } & \\
\hline Low & 91 & 01.9 & 8 & 8.1 & \multirow{3}{*}{8.10} & $3 \cdot 56-$ & \multirow{3}{*}{$<0.001$} \\
\hline High & 59 & 58.4 & 41 & 51.6 & & 18.46 & \\
\hline \multicolumn{6}{|l|}{ Mother's age } & & \\
\hline$<20$ years oldor $\geq 35$ years old & 56 & 58.9 & 39 & 41.1 & \multirow{2}{*}{0.17} & $0.08-$ & \multirow{2}{*}{$<0.001$} \\
\hline $20-35$ years old & 94 & 89.5 & 11 & 10.5 & & 0.35 & \\
\hline
\end{tabular}

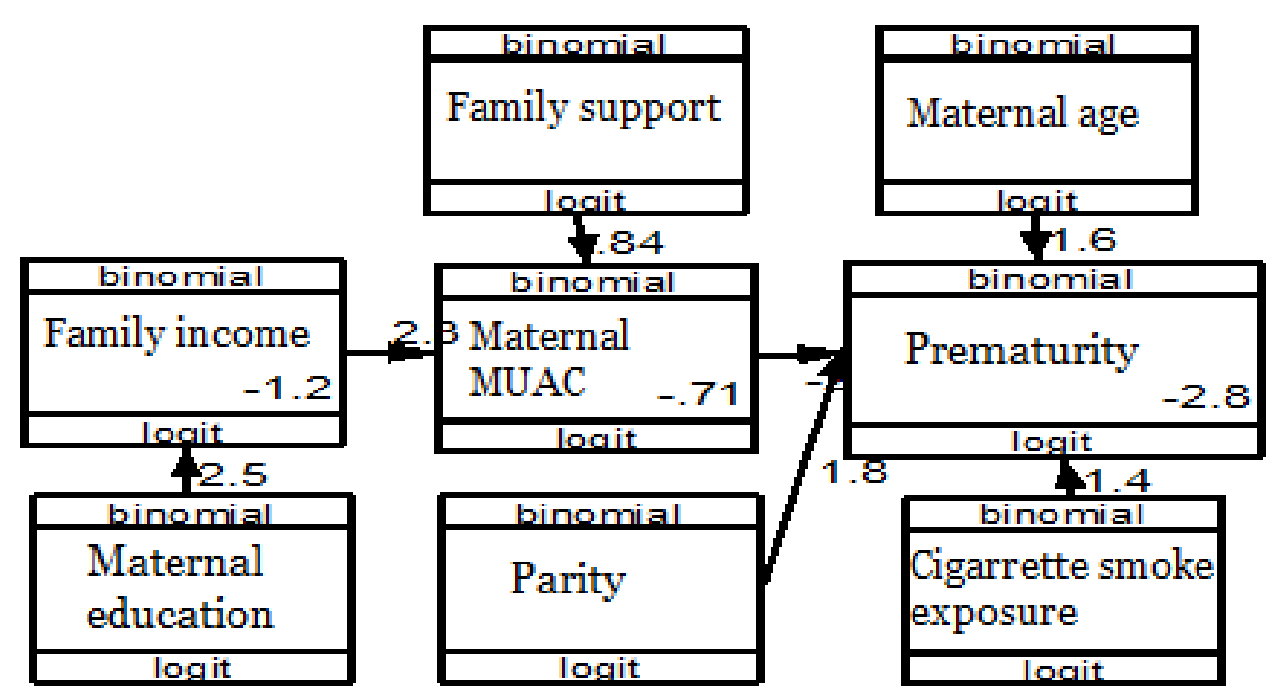

Figure 1. Structural model with estimate

\section{The results of path analysis}

Figure 1 and Table 3 explained that there was a direct effect between normal nutritional status during pregnancy $(\geq 23.5 \mathrm{~cm})$ and it was statistically significant. Pregnant women with normal nutritional status had a logodd score of preterm birth of 2.00 units lower than pregnant women with poor nutritional status $(<23.5 \mathrm{~cm})$. Normal pregnant nutritional status $(\geq 23.5 \mathrm{~cm}$ ) may reduce the risk of preterm birth $(b=-2.00$; CI 95\%=-2.92--1.08; $\mathrm{p}<0.001)$. 
Journal of maternal and child health (2018), 3(2): 138-145

https://doi.org/10.26911/thejmch.2018.03.02.06

There was a direct effect of family support and it was statistically significant. High family support had a logodd score of preterm births of 0.93 units compared to

Table 3. Path analysis results on the determinants of preterm birth

\begin{tabular}{|c|c|c|c|c|c|c|}
\hline \multirow{2}{*}{$\begin{array}{c}\text { Dependent } \\
\text { Variable }\end{array}$} & & \multirow[b]{2}{*}{ Independent Variable } & \multirow[b]{2}{*}{$\mathbf{b}$} & \multicolumn{2}{|c|}{$95 \% \mathrm{CI}$} & \multirow[b]{2}{*}{$\mathbf{p}$} \\
\hline & & & & $\begin{array}{l}\text { Upper } \\
\text { Limit }\end{array}$ & $\begin{array}{c}\text { Lower } \\
\text { Limit }\end{array}$ & \\
\hline \multicolumn{7}{|l|}{ Direct Effect } \\
\hline Preterm Birth & $\leftarrow$ & Maternal age & 1.58 & 0.65 & 2.50 & 0.001 \\
\hline Preterm Birth & $\leftarrow$ & Ambient smoke exposure & 1.42 & 0.41 & 2.44 & 0.006 \\
\hline Preterm Birth & $\leftarrow$ & $\begin{array}{l}\text { Maternal nutritional status } \\
\text { during pregnancy }\end{array}$ & -2.00 & -2.92 & -1.08 & $<0.001$ \\
\hline Indirect Effect & $\leftarrow$ & Parity & 1.77 & 0.87 & 2.67 & $<0.001$ \\
\hline $\begin{array}{l}\text { Maternal nutri- } \\
\text { tional status } \\
\text { during pregnancy }\end{array}$ & $\leftarrow$ & Family support & 0.93 & 0.24 & 1.61 & 0.008 \\
\hline $\begin{array}{l}\text { Maternal nutri- } \\
\text { tional status } \\
\text { during pregnancy }\end{array}$ & $\leftarrow$ & Family income & 2.26 & 1.57 & 2.95 & $<0.001$ \\
\hline $\begin{array}{l}\text { Family income for } \\
\text { pregnancy } \\
\text { N observation }=200 \\
\text { Log likelihood }=-272\end{array}$ & $\leftarrow$ & Maternal education & 2.45 & 1.76 & 3.17 & $<0.001$ \\
\hline
\end{tabular}

\section{DISCUSSIONS}

\section{The Effect of Maternal Education on Preterm Birth}

The results of this study indicated that maternal education level significantly and indirectly affect the preterm birth. This was supported by a study about low maternal education which increased the risk of preterm birth (Murad et al., 2014; Ahankari et al., 2017). This was also in line with a study by Bushnik et al. (2017) which stated that the risk of preterm birth was associated by maternal education.

With low educational level, it was highly necessary to consider that the level of education factors greatly affect a person to easily get and understand the knowledge about the nutrients that they have (Fikawatiet al., 2012). Women who were either malnourished or well-nourished were classified according to the standards set by the World Health Organization. The reason may be maternal nutritional status during pregnancy because it played an important role in low family support. High family support may reduce the risk of preterm birth $(\mathrm{b}=$ $0.93 ; 95 \% \mathrm{CI}=0.24$ to $1.61 ; \mathrm{p}=0.008$ ). worsening birth delivery, determining the length of pregnancy, infant birth weight, preterm birth, and other adverse conditions. During pregnancy, mothers need more food, various diets, and additional macronutrient supplementation to fulfill the extra body needs in the second and third trimesters (Murad et al., 2014).

\section{The Effect of Family Income for Pregnancy on Preterm Birth}

The result of this study showed that the family income for pregnancy significantly and indirectly affected preterm birth through the nutritional adequacy of pregnancy.

This was supported by a study about family income for pregnancy which increased the preterm birth (Bushnik et al., 2017; Murad M et al., 2014). This was also in accordance with a study done by Sharma and Mishra (2013), which stated that low socioeconomic status worsen the situation and an inter-generational cycle and it became hard to remove. 
Low levels of education can limit the access to employment and other social resources and it increased the risk of low income (Bushnik et al., 2017).

\section{The Effect of Maternal Nutritional Status on Preterm Birth}

The analysis result of this study showed a direct effect of preterm birth incident which was statistically significant. With normal nutritional adequacy $(\geq 23.5 \mathrm{~cm})$, it can affect and reduce the risk of preterm birth. In contrary, the conditions of lack of nutrient adequacy $(<23.5 \mathrm{~cm})$ have a high risk to the occurrence of preterm birth.

This was supported by the result of the study about low nutritional status which can increase the risk of preterm birth (Kavle et al., 2017; Cetin and Laoreti, 2015). Similar study also done byHansson et al, (2016) which stated that inadequate and excessive maternal nutrition before and during pregnancy has a potentially severe effect on their children.

Poor economic conditions were primarily defined as the inability to buy nutritious food for households, such as dairy products (milk), fish, chicken, eggs, and meat. Pregnant women claimed that they want certain foods to support their pregnancies, but they were unable to afford these foods and need guidance on how to increase the consumption of nutritious foods, based on economic constraints (Girard et al., 2012).

\section{The Effect of Ambient Smoke Expo- sure on Preterm Birth}

The analysis result of this study showed a direct effectof preterm birth incident which was statistically significant. With high ambient smoke exposure, it can affect and increase the risk of preterm birth. In contrary, with low condition of ambient smoke exposure, it can reduce the risk of preterm birth.
This was supported by a study of high ambient smoke exposurewhich has risk to increase preterm birth (Cheng et al., 2017; Cui et al., 2016). This was also in line with a study by Dahlin et al. (2016), which stated that the use of tobacco and smoking in pregnancy was associated with the risk of preterm birth.

The household members who were also smokers served as a strong predictor of ambient smoke exposure. The side effects of inhaling cigarette smoke during pregnancy can lead to adverse effects on the fetus in the womb, in pregnant women who consume cigarettes, it can lead to giving birth to dead infants compared to pregnant women who do not smoke. Nicotine is a vasoconstrictor substance that can lead to deep protein circulation in the developing fetus and slowed the heart beat of the fetus which can lead to disruption of the fetal nervous system (Astuti and Susanti et al., 2016).

\section{The Effect of Family Support on Preterm Birth}

The analysis result of this study showed an indirect effect through pregnancy adequacy nutrition with preterm birth which was statistically significant. With strong family support, it can affect and reduce the risk of preterm birth. In contrary, low family support conditions may increase the risk of preterm birth.

This was supported by a study about strong family support which can increase the preterm birth (Juwita, 2018), maternal nutrition fulfillment was influenced by one of the factors, that was support from husband, family, society. Without the support of the closest person, a goal would not be achieved properly.

Pregnant women strongly need family support so that families also need to gain sufficient knowledge to do their obligation for the family (Andarmoyo, 2012). The perceived support of the family and especially 
the husband's role as the head of the family was important (Abdollahpour, 2015).

\section{6 . The effect of parity on preterm birth}

The analysis result of this study showed a direct effect of preterm birth incident which was statistically significant. High parity can affect and increase the risk of preterm birth. Otherwise, a low parity condition can reduce the risk of preterm birth.

This study is consistent with (Wahyuni and Rohani, 2017 and Maita (2015), which stated that strong family support and low parity decreased the risk of preterm birth.

Mothers who have never been pregnant or give birth have a greater health risk compared to mothers who had given birth 1 or 2 times. If the mothers were too often to give birth, the uterus would become weaker because of scarring of the uterus as a result of repeated pregnancy. This scar tissue caused inadequate supply of blood to the placenta, therefore, the placenta did not get enough blood flow to channel the nutrients to the fetus and it lead to the disruption of the fetal growth (Health Department of RI, 2006).

\section{The effect of maternal age on preterm birth}

The analysis result of this study showed a direct effect of preterm birth incident which was statistically significant. Productive maternal age (20-35 years old) can affect and reduce the risk of preterm birth. On the other hand, low productive mothers $(<20$ years or $\geq 35$ years old) may increase the risk of preterm birth.

Maternal age $>20$ years old or $<35$ years old reduced the risk of preterm birth (Baer et al., 2017; Fuchs et al., 2018; Girsen et al., 2018).

Physically and mentally, a very proper age in terms of pregnancy was about 20-35 years old, because at these ages, the mother was biologically has developed reproductive organs which worked well and signified the fertile time, and also good psychological factors so that various factors were not affected which can be the cause of complications in pregnancy such as miscarryage, bleeding, and death (Hidayati, 2016).

\section{REFERENCES}

Abdollahpour S, Ramezani S, and Khosravi A. (2015). Perceived Social Support among Family in Pregnant Women. International Journal of PediatricsMashhad, 3(5): 879-888. doi: 10.22038/ IJP.2015.4703.

Ahankari A, Bapat S, Myles P, Fogarty A, Tata L (2017). Factors associated with preterm delivery and low birth weight: a study from rural Maharashtra, India', F10ooResearch, 6(0): 72. doi: 10.12688/f10ooresearch.10659.1.

Andarmoyo. (2012). Personal Hygiene, Konsep, Proses, Aplikasi dalam Praktik Keperawatan. Yogyakarta : Graha Ilmu.

Astuti S, Susanti AI dan Elista R. (2016). Gambaran Paparan Asap Rokok pada Ibu Hamil Berdasarkan Usia Kehamilan di Desa Cintamulya Kecamatan Jatinangor Kabupaten Sumedang: 2(38): 22-27.

Baer RJ, Yang J, Berghella V,Chambers CD, Coker TR, Kuppermann M (2017). Risk of preterm birth by maternal age at first and second pregnancy and race/ethnicity. Journal of Perinatal Medicine. doi: 10.1515/jpm-2017-0014.

Bushnik T, Yang S, Kaufman JS, Michael S. (2017). Socioeconomic disparities in small-for- gestational-age birth and preterm birth. Statistics Canada, Health Reports, Catalogue no. 82o03-X, 28(11): 3-10. doi: 82-003-X.

Cetin I, Laoreti A. (2015). The importance 
of maternal nutrition for health. Journal of Pediatric and Neonatal Individualized Medicine, 4(2): 1-11. doi: 10.7363/040220.

Cheng K-W, Chiang W-L, and Chiang T-L. (2017). In utero and early childhood exposure to secondhand smoke in Taiwan: a population-based birth cohort study. BMJ Open, 7(6): e014016. doi: 10.1136/ bmjopen-2016-014016.

Cui H, Gong TT, Liu CX, Wu QJ. (2016). Associations between Passive Maternal Smoking during Pregnancy and Preterm Birth: Evidence from a MetaAnalysis of Observational Studies. Plos One, 11(1): e0147848. doi: 10.1371/ journal.pone.0147848.

Dinas Kesehatan Provinsi Jawa Tengah (2015). Profil Kesehatan Provinsi Jawa Tengah. Dinas Kesehatan Provinsi Jawa Tengah: 48-49. Available at: dinkesjatengprov.go.id/ v2015/dokumen/profil2015/Profil_2015_fix.pdf.

Fikawati S, Wahyuni D, dan Syafiq A. (2012). Status Gizi Ibu Hamil dan Berat Lahir Bayi pada Kelompok Vegetarian. Makalah Kesehatan 16(1).

Fuchs F, Monet B, Ducruet T, Challet N, Audlbert F (2018). Effect of maternal age on the risk of preterm birth: A large cohort study', PLoS ONE, 13(1): $1-10$.

Gebreslasie K (2016). Preterm Birth and Associated Factors among Mothers Who Gave Birth in Gondar Town Health Institutions. doi: 10.1155/2016/4703138.

Girard AW, Dzingina C, Akogun O, Mason JB, and McFarland DA. (2012). Public health interventions, barriers, and opportunities for improving maternal nutrition in Northeast Nigeria. Food and Nutrition Bulletin, 33, S51-S70.

Girsen AI, Mayo JA, Wallenstein MB,
Gould JB, Carmichael SL, Stevenson DK, Lyell J et al. (2018). What factors are related to recurrent preterm birth among underweight women?. Journal of Maternal-Fetal and Neonatal Medicine. Taylor \& Francis, 31(5): 560566. doi: $10.1080 / 14767058.2017 .12-$ 92243.

Hansson F, Persson L- $\AA$ and Rahman A. (2016). A population-based study in Matlab, Banglades. (January).

Juwita R. (2018). Hubungan Konseling Dan Dukungn keluarga Terhadap Kepatuhan Ibu Hamil Mengkonsumsi Tablet Fe. STIKes Tengku Maharatu Riau. 3(1): 112-120.

Kavle JA, Landry M (2017). Maternal educational status at birth, maternal educational advancement, and neurocognitive outcomes at age 10 years among children born extremely preterm. 111. doi: 10.1038/pr.2017.267.

Murad M, Arbab M, Khan MB, Abdullah S, Ali M, Tareen S, Khan MW (2014). Study of Factors Affecting and Causing Low Birth Weigh. Journal of Scientific Research, 6(2): 387-394.

Sharma M and Mishra PS. (2013). Maternal risk factors and consequences of low birth weight in Infants. IOSR Journal of Humanities and Social science, 13(4): 39-45.

Sulistiyawati A. (2009). Asuhan Kebidanan pada Ibu nifas. Yogyakarta: CV Andi Offset

WHO. (2017). Preterm birth. WHO. Available at: http://www.who.int/mediacentre/factsheets/fs363/en/ (Accessed: 25 January 2018).

Zhang, YP, Liu XH, Gao SH, Wang, JM, Gu, YS, Zhang JY, Zhou X et al. (2012). Risk Factors for Preterm Birth in Five Maternal and Child Health Hospitals in Beijing'. 7 . 